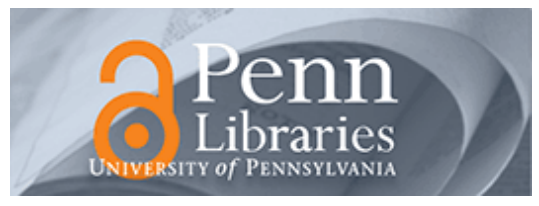

University of Pennsylvania

ScholarlyCommons

January 2003

\title{
The Andreia of the Hippocratic Physician and the Problem of Incurables
}

Ralph M. Rosen

University of Pennsylvania, rrosen@sas.upenn.edu

H.F. J. Horstmanshoff

Follow this and additional works at: https://repository.upenn.edu/classics_papers

\section{Recommended Citation}

Rosen, R. M., \& Horstmanshoff, H. J. (2003). The Andreia of the Hippocratic Physician and the Problem of Incurables. Retrieved from https://repository.upenn.edu/classics_papers/10

Postprint version. Published in Andreia: Studies in Manliness and Courage in Classical Antiquity, Mnemosyne: Bibliotheca Classica Batava. Supplementum 238, edited by Ralph M. Rosen and Ineke Sluiter (Leiden; Boston: Brill, 2003), pages 95-114. The author has asserted his right to include this material in ScholarlyCommons@Penn.

This paper is posted at ScholarlyCommons. https://repository.upenn.edu/classics_papers/10

For more information, please contact repository@pobox.upenn.edu. 


\title{
The Andreia of the Hippocratic Physician and the Problem of Incurables
}

\author{
Abstract \\ One of the most enduring metaphors of Western medicine has been its conception of illness as an \\ invasive enemy against which the patient and doctor must join forces to do battle. Indeed, the more \\ invisible and mysterious the processes of disease, the more vividly do people seem to invoke the \\ metaphor. So it is not surprising to find that in antiquity, when the etiology and control of disease was \\ considerably more elusive than it is today, the notion of the body as a battlefield pervaded the medical \\ treatises both implicitly and explicitly. ${ }^{1}$

\section{Comments} \\ Postprint version. Published in Andreia: Studies in Manliness and Courage in Classical Antiquity, \\ Mnemosyne: Bibliotheca Classica Batava. Supplementum 238, edited by Ralph M. Rosen and Ineke Sluiter \\ (Leiden; Boston: Brill, 2003), pages 95-114. The author has asserted his right to include this material in \\ ScholarlyCommons@Penn.
}




\section{The Andreia of the Hippocratic Physician and the Problem of Incurables}

Ralph M. Rosen and H. F. J. Horstmanshoff

One of the most enduring metaphors of Western medicine has been its conception of illness as an invasive enemy against which the patient and doctor must join forces to do battle. Indeed, the more invisible and mysterious the processes of disease, the more vividly do people seem to invoke the metaphor. So it is not surprising to find that in antiquity, when the etiology and control of disease was considerably more elusive than it is today, the notion of the body as a battlefield pervaded the medical treatises both implicitly and explicitly. ${ }^{1}$ As the other essays in this collection make abundantly clear, when it came to real-life warfare in ancient Greece, the principal virtue was andreia, a term which, despite its many semantic nuances, became generally synonymous with military prowess and an almost heroic capacity for bravery. We might expect, therefore, that the Hippocratic physician, engaged as he was in his peculiarly relentless battle against disease, would be readily characterized in the treatises as andreios. In fact,

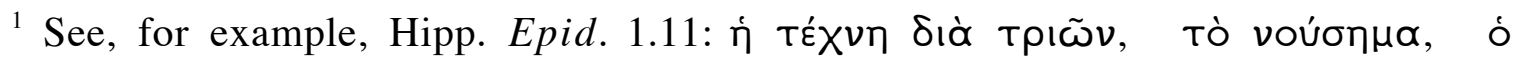

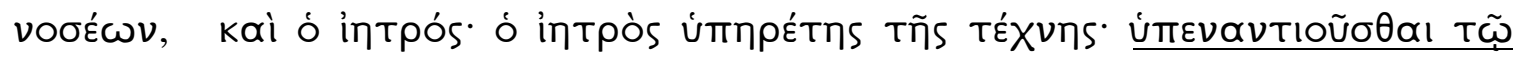

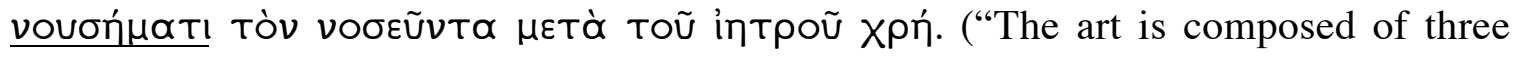
things: the sickness, the patient, and the physician. The physician is the servant of the art, and the patient must join forces with the doctor against the disease."). Parry 1969, 11516 notes the prevalence of military metaphors in Thucydides' description of the plague at Athens (2.47-54). 
however, there seem to be no instances in all of the Hippocratic corpus where this happens. Andreia certainly occurs in contexts where an individual's moral character is discussed as a function of bodily constitution, nutrition or environment, ${ }^{2}$ but it does not happen to be singled out as a virtue particularly associated with the medical profession. Even the deontological works, which self-consciously address matters of professional demeanor and business ethics, never actually use the term in the context of how the Hippocratic doctor ought to behave. Do we conclude, then, that andreia was simply not felt to be especially applicable to this type of ancient "warrior"? If so, when the ancient physician behaved with what we might call "courage" or "steadfastness," did they themselves, and the non-professional public, conceptualize these qualities differently from more traditional forms of andreia?

${ }^{2}$ E.g., De Diaeta 1.28: (on what conditions at conception are necessary for a man to turn

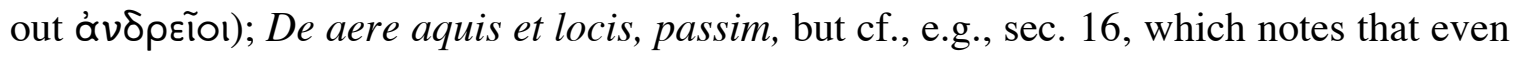

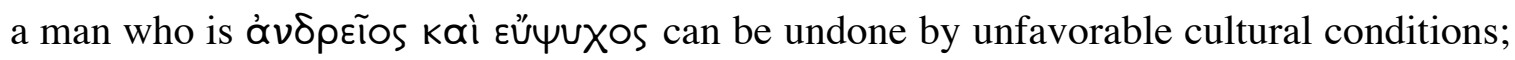

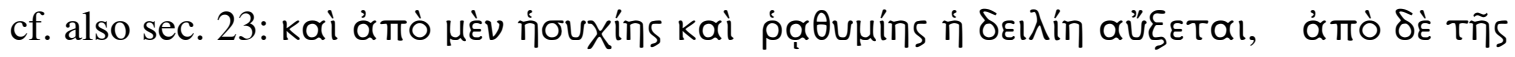

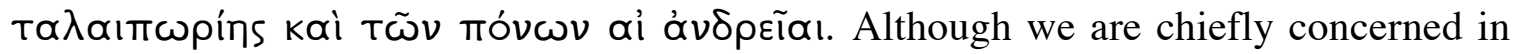
this chapter with Hippocratic texts, it is noteworthy that Galen too seems not to have used the term á $v \delta \rho \varepsilon^{\prime} \alpha$ to refer explicitly to a physician's virtue. But see below note [15], where Galen uses the adverbial form, á $v \delta \rho \varepsilon i \omega s$, ironically of certain misguided physicians. On the courage of patients in enduring pain (and its philosophical associations), see Schrijvers 1990. 
It may be that in an age when illnesses were generally thought to arise from the disequilibrium of the body's physiology, the notion of the disease as "enemy" was, in fact, so abstract and metaphorical that andreia seemed just a little too grounded in cotidian reality to serve as le mot juste for a physician's primary virtue. Bodies became ill, in other words, not so much because specifically identifiable "agents" attacked them, but because certain, sometimes nebulously construed, forces - nutrition, climate, selfneglect, and so on-altered their internal constitutions in destructive ways. It is useful in this regard to consider how powerfully microbiology has changed our own conceptions of disease. Ever since we could actually see the way "germs" can cause pathology, the notion of a "fight" against disease has become much less a metaphor than an accurate description of prevailing Western approaches to medicine. ${ }^{3}$ But for the ancient doctor, the battle against disease may have been less "personalized" than it often is today, and this may explain why andreia, which could so readily conjure up vivid images of human combat, was felt to be less appropriate as a description of his particular battles. It is somewhat easier, after all, to anthropomorphize microbial entities as human enemies than the natural forces that loom so large in ancient etiologies of disease.

Despite the fact that the lexical term, andreia, was not explicitly used to describe the idiosyncratic virtues of the Hippocratic physician, however, we would like to argue in

\footnotetext{
${ }^{3}$ For metaphors of warfare, invasion, victory and defeat in modern culture, see Sontag 1977, 62-66. She speaks, for example, of "the American cancer establishment, tirelessly hailing the imminent victory over cancer; the professional pessimism of a large number of cancer specialists, talking like battle-weary officers mired down in an interminable colonial war..."
} 
this chapter both that they conceptualized their activity as a form of andreia, and that, in general, patients and the public at large expected from their doctors behavior which in other contexts would allow them to be considered andreioi. We propose to make this case by focusing on the Hippocratic discussions of a particularly troubling point of medical ethics, namely, how a doctor should behave in the face of obviously incurable patients. Here, as we shall find, a classic dilemma arises when a profession ostensibly dedicated to healing disease and the relief of human suffering confronts a kind of battle it can never hope to win. As the treatises show, opinions were divided about the proper way to handle such cases, and rationality was not always their main criterion. Personal ego and the reputation of the profession itself were often at stake in this controversy, and questions of duty, honor and integrity evidently came into play on both sides. The treatises reveal, we believe, that the accusations and apologies on this issue fundamentally concerned what can only be regarded as the andreia of the physician: was the refusal to treat incurables a dereliction of duty? did it imply a form of cowardice, like that of the proverbial rhipsaspis, who tosses away his armor and flees a terrifying enemy? $?^{4}$ Or, on the other hand, did such a physician justify his position by applying a more nuanced calculus of knowledge and reason to the notion of courageous behavior in medicine?

Even allowing for the substantive and chronological diversity of the Hippocratic corpus, it is reasonably clear that, as we will see in greater detail below, the "Hippocratic

\footnotetext{
${ }^{4}$ Jouanna 1999, 110, uses the term "noble flight" to describe how people might perceive a physician who refused to treat an incurable patient: “...a gesture so at variance with the heroic ideal, [that] the physician may seem to have fled from the battle against illness, throwing down his arms in the face of danger and uncertainty."
} 
position" on this issue was that in some cases it was indeed best not to take on incurable cases. In responding to anonymous or hypothetical detractors, these treatises, once again, never invoke andreia as such, but the arguments they deploy bear a remarkable resemblance to the famous discussion of the term in Plato's Laches. In fact, all the interlocutors in the dialogue at one point or another invoke medicine (iatrikê) or physicians (iatroi) in their attempts to articulate a definition of andreia. Insofar as the dialogue ends aporetically, it is difficult to glean from it a definitive Platonic stance on whether physicians could or should possess andreia, but the discussion nevertheless clearly suggests that an association between andreia and iatrikê was commonly made, even if some people found it unconvincing. As we shall argue, the discussion in Laches not only clarifies the Hippocratic arguments defending their position on incurables, but also suggests that at the core of this defense lay the fundamental assumption that something akin to andreia ought to be seen as the primary virtue of the Hippocratic physician.

It is often noted that ancient medicine was a very "public" activity. Since the profession was unregulated and there were probably as many incompetent as competent physicians, the public was often understandably wary of a physician's claims to expertise. Hence we continually hear of public debates between rival practitioners or schools, and both the Hippocratic treatises, and later, Galen, depict a climate in which physicians seemed constantly engaged in some form of debate, squabbling or even downright abuse. It is no wonder that when they actually saw sick patients, they would doubtless have felt 
scrutinized by a wider public, ${ }^{5}$ interested in assessing not only their skill at healing, but their demeanor and attitude along the way. Their metaphorical battle against disease was as much a spectacle as any real battle, and the physician's virtues as a soldier in this battle were every bit as public as those of a real soldier. ${ }^{6}$ One can see, therefore, why a Hippocratic physician's decision to withhold treatment from certain cases would have been a matter of concern that extended far beyond his private dealings with the unfortunate patient. For just as the soldier who shirks his responsibilities on the battlefield is in danger of being branded anandreios (unless he can offer a persuasive explanation for behavior that on the surface will always appear reprehensible), so the physician, whose duty to heal the sick and relieve human suffering is professed time and again in the treatises with an almost heroic fervor, can easily give the appearance of repudiating his own principles of combat.

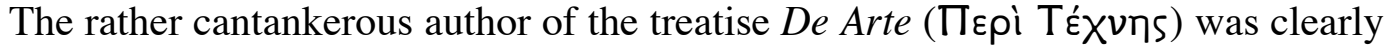
reacting to such accusations from critics who regarded the Hippocratic refusal to treat incurables as evidence that medicine was a sham "art" to begin with. Indeed, this author regards his rhetorical mission as battle against ignorance, which seems to require as much courage and bravery as the battle against disease itself:

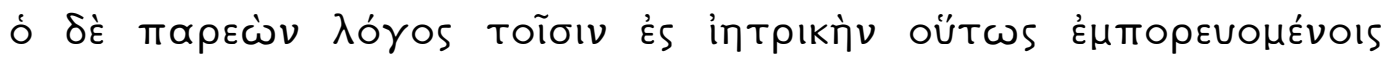

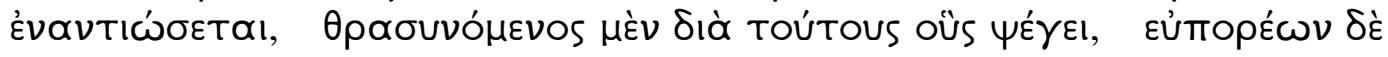

${ }^{5}$ See Jouanna 1999, 75-80 for a discussion of the "public" aspects of Hippocratic medicine.

${ }^{6}$ Battle metaphors for disease and treatment abound in the Hippocratic corpus. Cf. von Staden 1987, 97-99, and Jouanna 1999, 141 and 342-3 for many examples. 


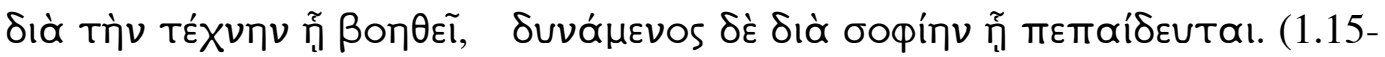
17)

...but the treatise at hand will oppose those who attack medicine thus, emboldening itself through those it blames, well supplied by the art which it defends, and powerful in the knowledge in which it has been educated.

When the author offers a definition of medicine in the third chapter, it is striking that he includes a statement about incurable patients:

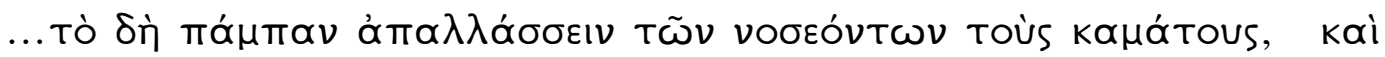

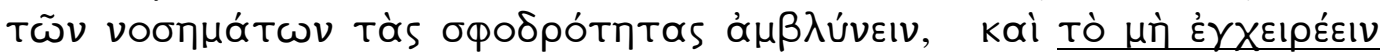

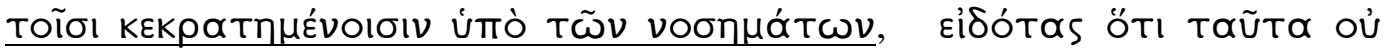

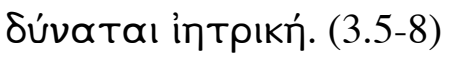

[medicine is]...broadly speaking to relieve the sufferings of the sick, to mitigate the severity of diseases, and not to attempt to treat those who are overpowered by disease, knowing that medicine has no power over these cases.

The last phrase about incurables reads almost as a deliberate provocation to potential detractors, especially given the phrasing of the first part of his definition, which stresses

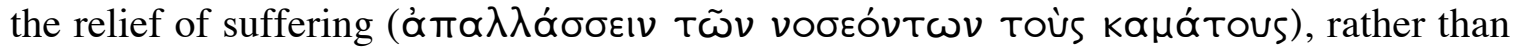
the actual curing of disease. ${ }^{7}$ Why, one might ask, should one withhold relief from an

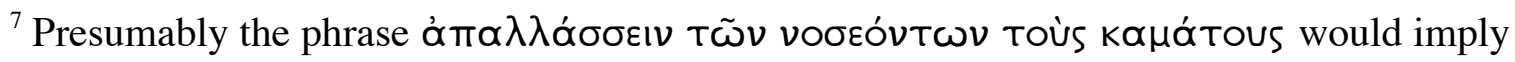
that a sick patient is not only relieved of his suffering, but also recovers from his illness, but this author seems somewhat evasive on this point. A clearer statement that the Hippocratic physician aimed both to cure his patients and to make him as comfortable as

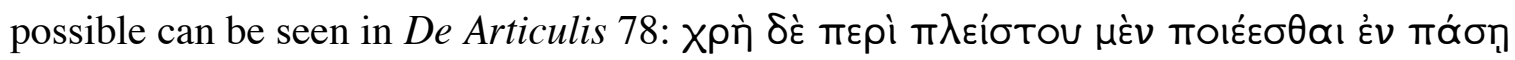

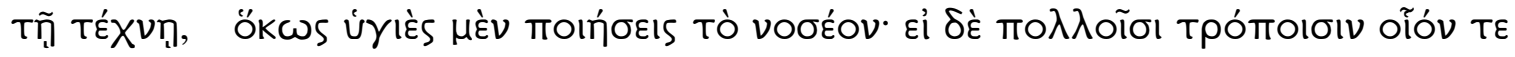

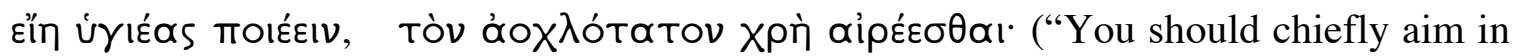
every aspect of medical practice to make the sick person healthy. And if you can produce 
obviously incurable patient $?^{8}$ But the author is either insensitive to this apparent paradox (i.e., claiming an art of relief, but withholding it from some patients) or more interested in addressing what he regards as the fundamental charge against medicine, that it just does not "work." As he says in chapter 4, people are unhappy because medicine cannot cure everyone. When people are cured, according to the detractors, it is merely because they would have been lucky enough to survive even without the intervention of a physician.:

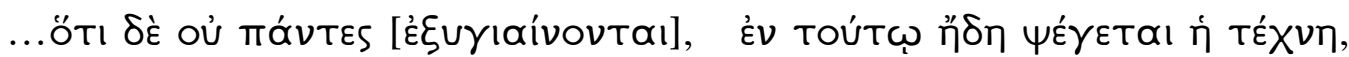

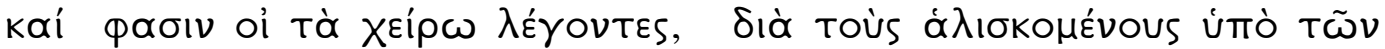

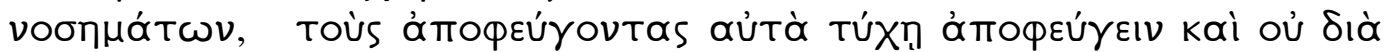
Tก̀v TÉXvฑv.

...but the art [of medicine] is blamed because not everyone [is restored to health], and those who repudiate [the art], because there are some who are defeated by diseases, say that those who manage to escape them, do so because they're simply lucky and not because of the art.

Our author does not deny the force of luck, but argues, as one might expect, that the technê of the physician demonstrably abets whatever fortune might hold for a patient (Chs. 5-7). Since most people, he argues, even those who never seek a doctor, would

health in a variety of ways, you should choose the method that causes the least discomfort").

${ }^{8}$ For a full treatment of the question of "incurable" diseases and patients in the Hippocratic corpus, see von Staden 1987 . Von Staden discusses at length the many ways "incurability" could be expressed in the corpus (cf. esp. 75-84), and notes that two approaches seemed current - a binary one (patients and diseases were deemed either curable or non-curable), and a gradational one (they might be curable or incurable depending on external contingencies or an idiosyncratic array of symptoms). 
agree that some sort of intervention is called for in the face of a disease (changing a diet or climate, for example), ${ }^{9}$ it is difficult to deny that a technê that rationalizes and systematizes such intervention would be even more useful to humanity than simply stumbling upon effective treatments haphazardly.

But one can see the trap that the author is unwittingly setting for himself with every step of his argument, and, ironically, we can anticipate the objection to a position advocating non-intervention in incurable cases. If the author, after all, has just finished arguing that one is generally better off not leaving the course of an illness up to chance and fortune, but rather should seek medical advice, why in the case of incurables, should one refuse to intervene, if only to alleviate suffering and (one might argue) make the body possibly more receptive to a chance recovery? The specific charge laid against the Hippocratic position, according to the author in $\mathrm{Ch} .8$, is that physicians limit themselves

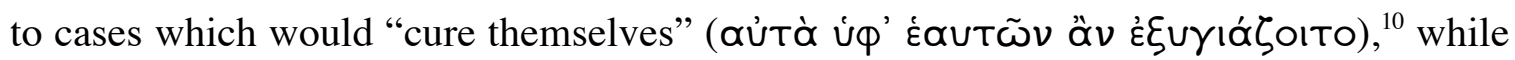

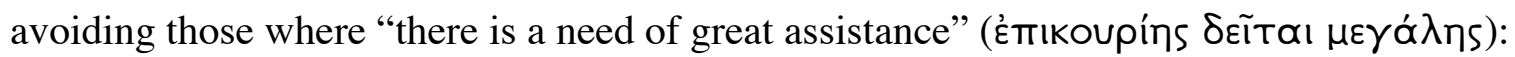

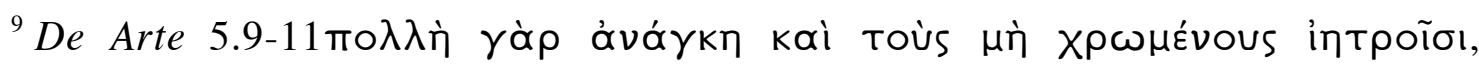

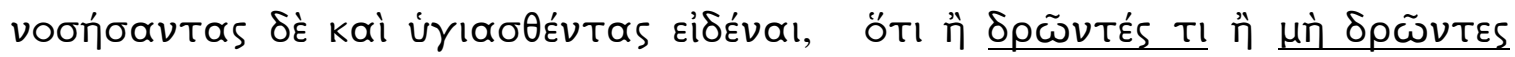

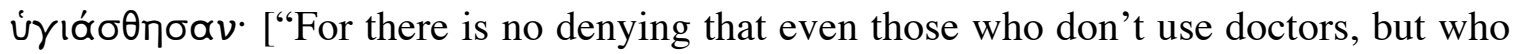
recover from illness, realize that they have been cured because of something that they've done or not done."]

${ }^{10}$ I take it that this really means something like this: "in cases where patients do recover, they would have recovered on their own, without the medical art" rather than that "physicians only take on cases which would otherwise cure themselves," since obviously physicians routinely treat patients who end up not being cured. The phrasing is elliptical 


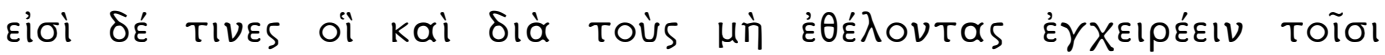

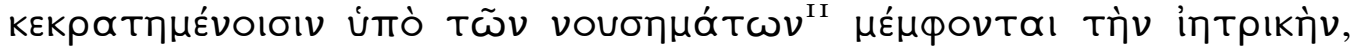

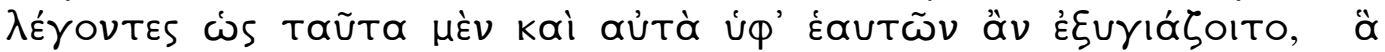

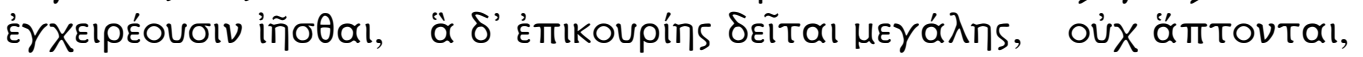

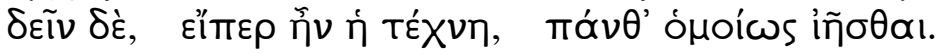

And there are some who also blame medicine because of those who are unwilling to take on patients who have been defeated by their disease; they say that the cases which they attempt to cure are those which which would be cured on their own anyway, but that they don't touch the cases where there is need of great assistance. But (they say), if medicine is in fact an art, then it ought to cure all cases alike.

The detractors maintain that if medicine were really a technê, it would at least attempt to cure all patients, ${ }^{12}$ not just the "easy" cases which would be cured anyway. This objection

here, but seems to assume that the physician will prognosticate about the patient's condition, and only decide to treat him if he calculates that there is a good chance of recovery. On Hippocratic prognostication and andreia, see below pp. [000].

${ }^{11}$ Cicero seems to be translating this expression in De Att. 16.15.5, when he turns in his letter from public affairs to his domestic troubles: sed me, mi Attice, non sane hoc quidem tempore movet res publica, non quo aut sit mihi quicquam carius aut esse debeat, sed desperatis etiam Hippocrates vetat adhibere medicinam.

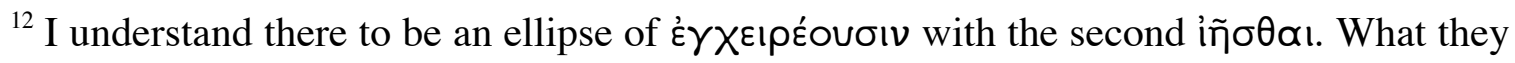
want is for a physician to take on any sick patient, regardless of the chances of recovery; they certainly would not assume that a physician would successfully cure every patient. In point of fact, there is plenty of evidence outside of this treatise that Hippocratic physicians did treat hopeless cases, and it seems clear that the matter was one of perennial debate. For discussion and references, see Wittern 1979, von Staden 1987, 76 n.1, 102-12, Jouanna 1999, 109-11; see also van der Eijk 1999. 
seems simple enough, but it has several revealing implications. First, it clearly assumes a normative model of medicine: if one is going to make the claim that medicine is a technê, then one will assume that a technê will behave according to certain protocols, that there are certain things it should do if it can legitimately be considered a technê. So if one claims that the technê of medicine is to do one thing (e.g., minister to the sick), you cannot then claim that it also does not do that very thing (e.g., when it says it will not treat the incurably sick). In other words, the refusal to treat incurables is here essentially portrayed by the detractors as a repudiation of the stated principles of the technê of medicine. Thus, the physician who takes such a position is put in a terrible bind, for he is exposed as either an unethical hypocrite or a simple charlatan who conspires with his colleagues to take on only those cases which will make their empty profession look good.

It is clear that the author of De Arte deeply resented the implication that the refusal to treat incurables constituted an ethical breach, and he spends the rest of Chapter 8 attempting to explain the position. ${ }^{13}$ The core of his explanation lies in an appeal to the proper knowledge of what medicine is and is not capable of doing, and the rational application of this knowledge. Simply put, he says in so many words that medicine has no business trying to fight a battle it cannot hope to win; and it is the technê itself which provides the knowledge necessary to determine when this might be the case:

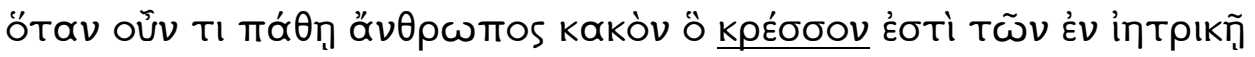

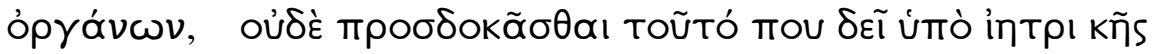

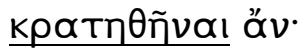

${ }^{13}$ See Cordes 1994, 122-24; for further bibliography on De Arte, see Cordes, p. 101, n. 63. 
So whenever a person suffers from something bad which is stronger than the tools available to medicine, then one can hardly expect that it can be defeated by medicine.

This leads him to conclude that some cases are simply "inappropriate" for the physician to take on, because he has no means strong enough to defeat the disease:

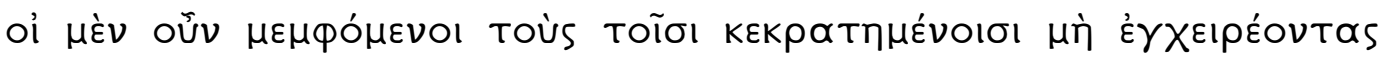

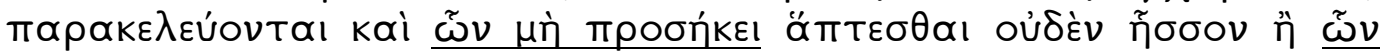

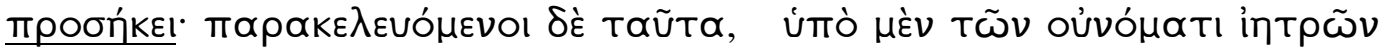

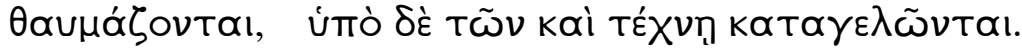

Those who blame physicians who don't take on incurable cases, urge them to treat inappropriate cases no less than appropriate ones. In urging this, they may be admired by people who call themselves physicians, but they are ridiculed by "real" physicians [lit.: phyicians versed in technê].

Behind this curious statement about "inappropriate" and "appropriate" cases, it seems, lies a contemporary clash between people who expect from their physicians an engaged compassion for the sick patient regardless of the illness, and physicians whose cool, rational attitude towards the nature of illness allows them to keep their distance from patients they deem incurable. This author, in fact, turns the tables and practically accuses any physician who takes on a desperate case of charlatanism ("physicians in name only"). Yet, from the second sentence quoted above, many people admired such a physician and presumably found his behavior ethically correct, if not plainly heroic. The author of $D e$ Arte stands his ground, however, maintaining that praise or blame emanating from such people is "foolish" (aphrones), and that the real physician should heed only those who have "rationally calculated at what point the activities of craftsmen become finally

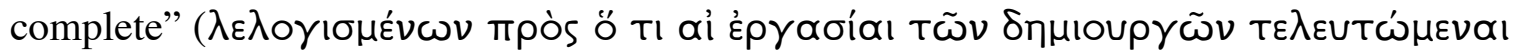

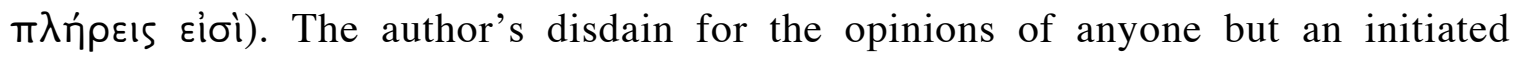


professional, indeed for any unphilosophized position on a medical subject, is palpable. It is easy to see from this little vignette that the Hippocratic physician who refused certain cases as a matter of principle might run counter to popular notions of medical ethics, and risked appearing not only arrogant, but also cowardly.

This controversy, then, between Hippocratic professionals and certain unspecified antagonists ultimately rests on two opposing ways of conceptualizing medicine as a form of combat. On the one hand, some (presumably non-Hippocratic) physicians, considered "foolish" by our author, plunge headlong into the battle against disease, indiscriminately

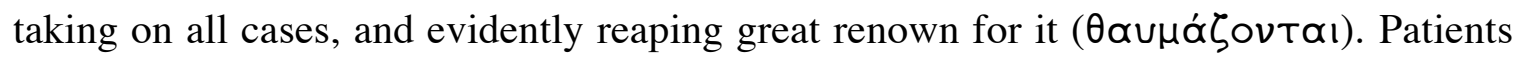
may die, and these physicians may well expect such an outcome from the start, but people admired the fact alone that they would take on even the most desperate cases, ${ }^{14}$ just as in other contexts the same people might admire a soldier whose andreia emboldened him against even the most insurmountable enemy. ${ }^{15}$ To the Hippocratic

${ }^{14}$ On the "public", performative aspects of ancient medicine, see Jouanna 1999, 75-76.

${ }^{15}$ Galen notes that in his time some physicians (whom he regards as disingenuous -

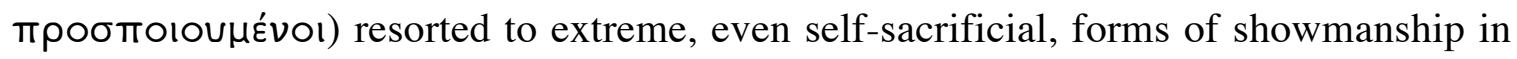
the name of andreia; cf. his remarks in De Meth. Med. 10 about physicians who, when ill

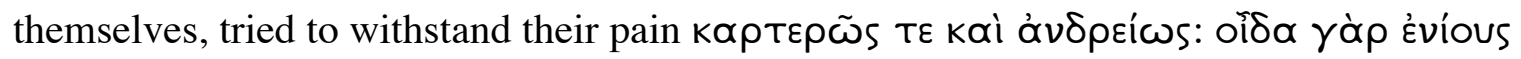

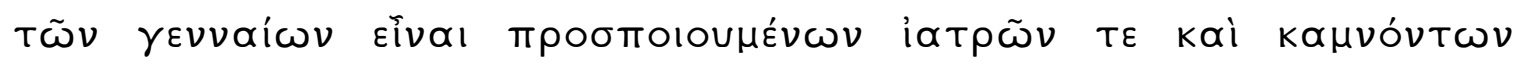

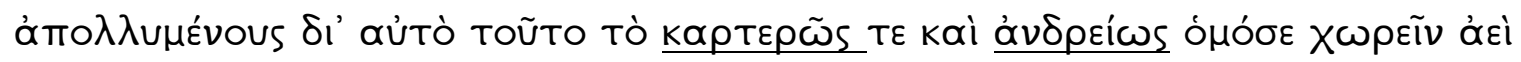

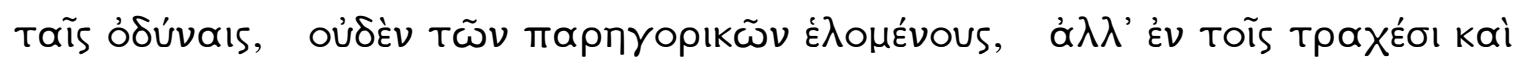

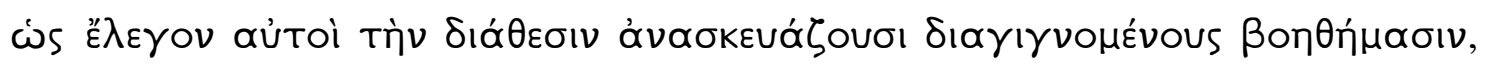

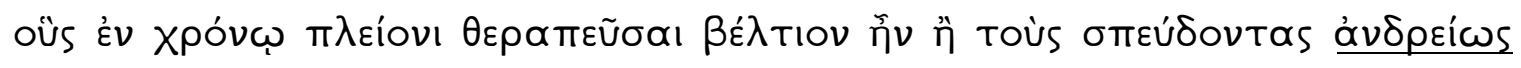


physician, however, such behavior was merely reckless and irresponsible. If, through technical knowledge and practical experience, one has rationally determined that a patient is incurable, the only conceivable reasons for treating him would be crass showmanship and self-promotion, which, he would of course argue, have nothing to do with proper medicine. At least the real soldier who fights against a more powerful enemy might get some satisfaction from the idea of martyrdom; whatever kudos a physician reaps from joining forces with an incurable patient against an undefeatable disease, however, is indecorously won, in the eyes of the Hippocratic physician, at the expense of his patient's life. It is, as the passage implies, a cheap victory that turns out upon closer examination to be more cowardly than heroic.

The author of De Arte bristles at the insinuation that Hippocratic physicians are morally negligent in refusing to treat incurables, and even though he does not explicitly articulate the debate in terms of andreia, it seems that it is something very much akin to

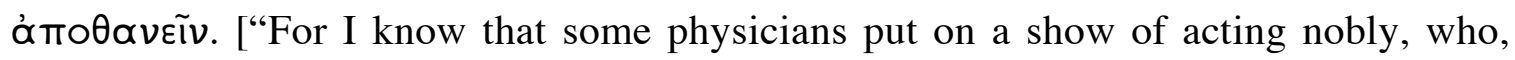
when sick themselves, perish by actually plowing headlong into their pain with fortitude and courage. They refuse to take any painkillers, but treat themselves with harsh remedies, which, as they themselves say, reverses their condition, when it would have been better for them to apply a longer therapy than to die courageously in their zeal."] Clearly, this is a crowd-pleasing form of andreia, not the kind Galen would recommend for true physicians. On the charges of cowardice against Galen himself in the biographical tradition (that he fled an uprising in Pergamum on one occasion, and on another that he fled from Rome to avoid the pestis Antoniniana of 166 AD), see Walsh, 1931. 
this virtue which he feels called upon to defend in the case of this particular Hippocratic practice. This becomes especially clear, we believe, when we read De Arte in the light of the discussion of andreia in Plato's Laches. There, the specific discussion of andreia is framed by the characteristically Socratic question of whether or not truly virtuous behavior requires knowledge and reason; likewise, in De Arte, the author defends his position on incurables by arguing that it is the only rational position to take, and the contrary position (of treating all cases regardless of the nature of their affliction) stems from ignorance and, by implication, vanity. As in De Arte, the discussion in Laches centers on a discontinuity beween popular conceptions of a particular social value and a more philosophized conception of it. When Socrates asks at 190e how his interlocutors, Laches and Nicias, would define andreia, Laches cannot believe he would ask such a simple, easily answered question. His response, that andreia consists in "remaining at

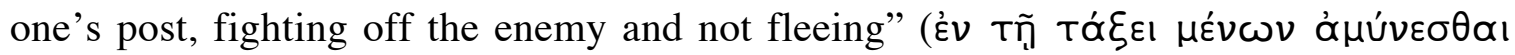

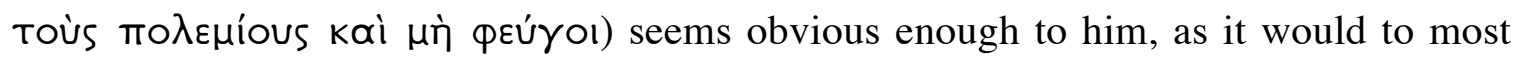
people ${ }^{16}$ even though Socrates predictably finds it inadequate as a definition. A similar notion of "endurance" at any cost in the face of the enemy seems to be what informs the popular belief intimated in De Arte that physicians should take on even the most

${ }^{16}$ See $197 b$, where Nicias, in a final flourish, distinguishes a popular conception of courage from his own more rigorous conception, which requires the application of knowledge: "And so the things that you and the many call 'courageous,' I call 'bold',

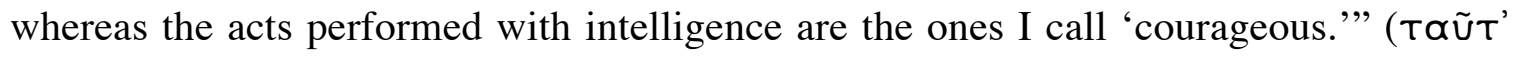

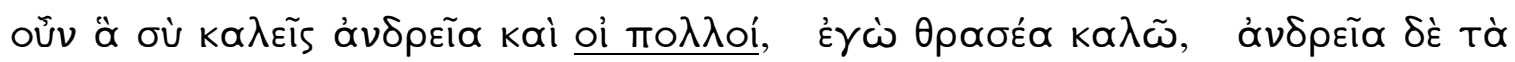

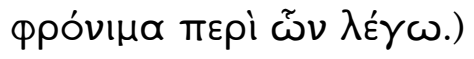


desperate patients. We can see, therefore, why the Hippocratic author of the treatise might feel rather defensive, since if the ethic of "remaining at one's post and not fleeing" was commonly transferred to the realm of medicine, those who did not do so, even for principled reasons, could easily be branded cowards.

In Laches, however, as in De Arte, the prudence of such unreflective engagement with an enemy is questioned. Socrates asks Laches at $193 \mathrm{a} 3$ to consider which of two men he would consider the more andreios:

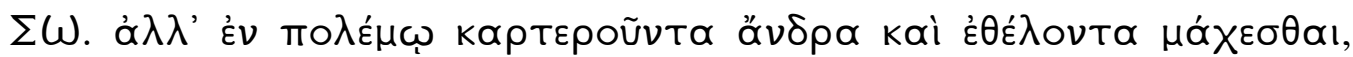

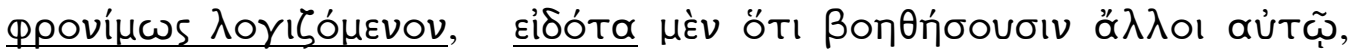

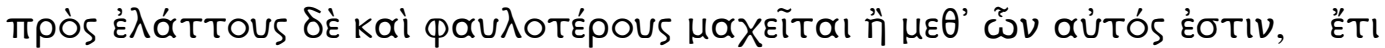

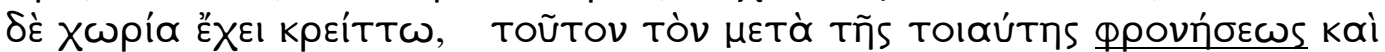

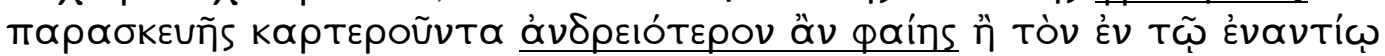

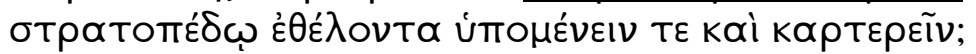

Well, suppose a man endures in battle, and his willingness to fight is based on wise calculation because he knows that others are coming to his aid, and that he will be fighting men who are fewer than those on his side, and inferior to them, and in addition his position is stronger: would you say that this man, with his kind of wisdom and preparation, endures more courageously or a man in the opposite camp who is willing to remain and hold out? [tr. Sprague]

Laches' first response is that the man in the "opposite camp" is the more brave; he is not given time to expatiate, but he doubtless reflects the attitude of most of his contemporaries. The first man might be admirable in his own way, but his endurance is safer and more predictable, and, Laches might say, it is less easy to describe him as "courageous," at least according to common usage, than the weaker opponent who holds out against him even to the point of his own defeat. Socrates, however, presses his point with similar examples, and Laches must agree with him at 193c9 that "people like this take risks and endure more foolishly than those who do it with techne" (kai $\mu$ ń $\nu$ mov

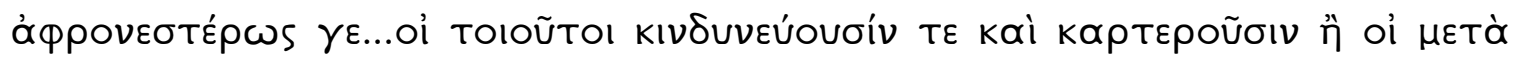




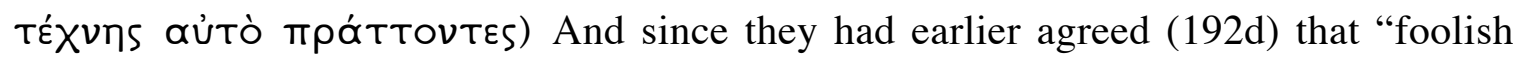

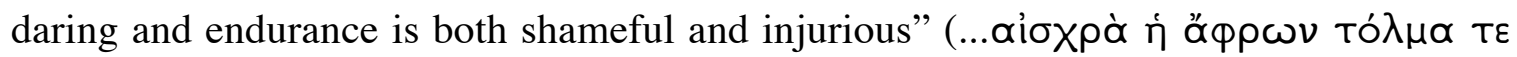

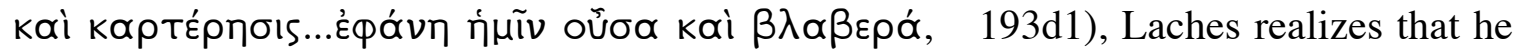
seems to have contradicted himself.

The connections between this section of Laches and the position of De Arte should be strikingly clear. Socrates' hypothetical "knowledgeable" soldier is precisely analogous to the Hippocratic physician in De Arte who undertakes only those cases which make sense for him based on his knowledge of the medical technê, while the valiant and tenacious, but weak and ignorant soldier, who endures in the name of an illunderstood notion of andreia, parallels the physician willing to take on even the most hopeless patient in the hope of reaping popular thauma.${ }^{17}$ Both Socrates and the author of De Arte are working to refine popular conceptions of "courageous" behavior by

${ }^{17}$ The closing paragraph of de Arte reiterates the connection between the knowledge that comes with a technê and proper ethical behavior-in this case, the refusal to treat very

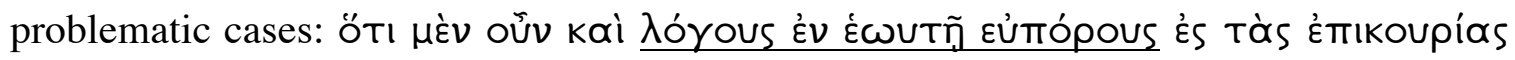

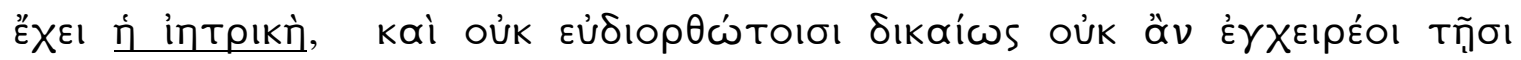

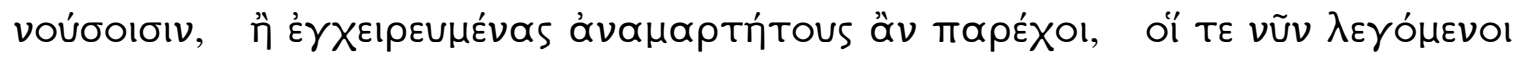

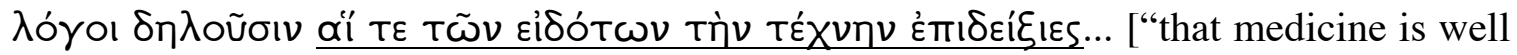
stocked with rational arguments in itself to come to its aid, and that it would justly not attempt to treat illnesses which are difficult to cure, or would make those who did take them on error-free, both the discussions of this treatise, and the demonstrations of those who understand the craft, make clear."] 
emphasizing the importance of knowledge and rationality for evaluating the outcome of our actions.

The argument in Laches proceeds even further, as Nicias takes over as Socrates' interlocutor and presses the notion, which he attributes ultimately to Socrates (194d), that

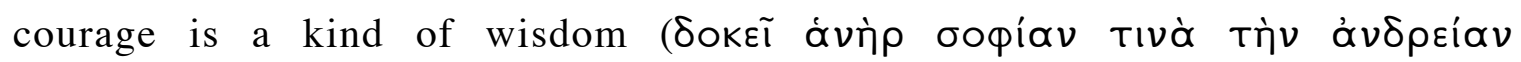
$\left.\lambda \varepsilon^{\prime} \gamma \varepsilon I \nu\right)$ - specifically the knowledge of "what is terrible and what is to be dared in war,

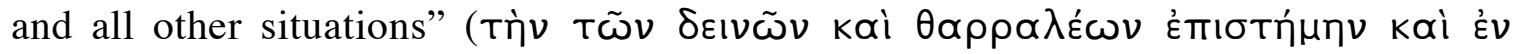

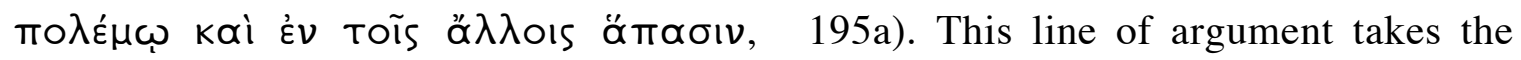
participants along a rocky path towards eventual aporia, ${ }^{18}$ but there are several significant ramifications for the ideas in De Arte along the way. In particular, physicians and the technê of medicine figure in this section as a veritable leitmotif, as the interlocutors wrestle with the problem of whether a physician's technical knowledge qualifies them to be considered andreioi. At first Laches brings up the example of physicians at 195b1 as a ploy to repudiate Nicias' equation of andreia and knowledge. Physicians certainly know what things are "terrible" (deina), but who would consider them "courageous," he asks sarcastically? Nicias agrees definitively he would not either (195b6). Now, this is just the beginning of a rather convoluted section in which the two keep returning to the example of physicians, and it will be useful to analyze their positions in some detail.

\footnotetext{
${ }^{18}$ At $199 \mathrm{c}-\mathrm{e}$, it becomes clear that the argument has led them to conclude that courage implies all the virtues and a knowledge of all goods and evils, even though they had previously agreed that it was only a part of virtue. At that point, the argument is dropped and the dialogue draws to a close.
} 
The two agree that they would not consider doctors to be "courageous," although Laches thinks that Nicias' argument equating knowledge with andreia ought to lead him to think so. Further, he places physicians in the same company as farmers and all other craftsmen (195b6), and suggests that it would be equally absurd to consider all of these courageous simply because they have some sort of technical knowledge. Nicias does not dispute the absurdity, but he dismisses Laches' example of the physician on the grounds that he inflates what they are actually capable of doing. Here, we have what amounts to a normative summary of the limits of contemporary medicine:

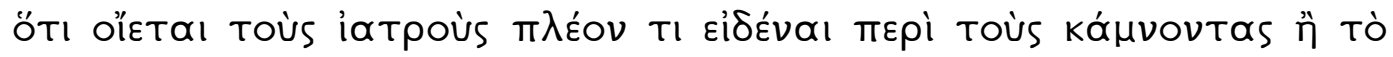

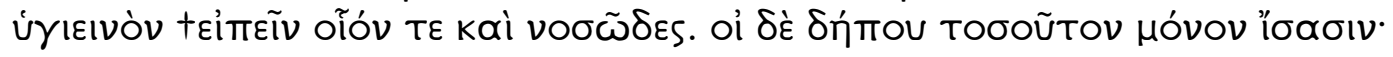

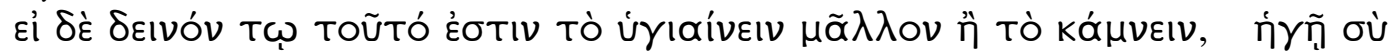

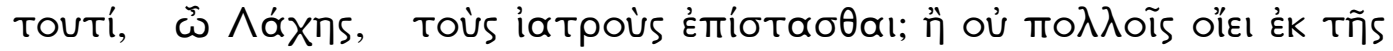

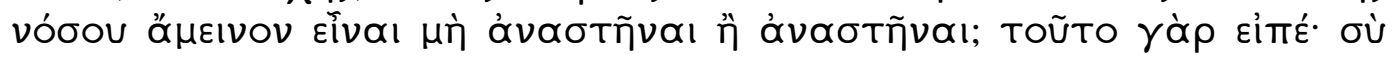

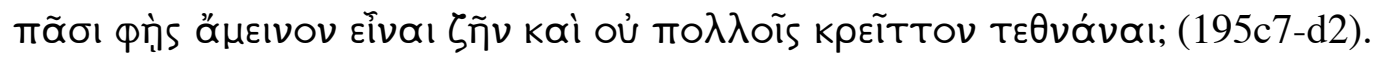

[Laches says what's not true...] Because he supposes that physicians know something more about the sick than how to say what is healthy and what is sick.But surely that's all they really know; and if recovery for a patient is more terrible than being sick, do you think, Laches, that doctors know this? Or do you not suppose that for many people it's better not to recover from an illness than to recover? I mean, tell me this: do you say that it's better in all cases for patients to live, and that it's not better for many of them to die?

Behind this line of questioning lies a debate about what sort of knowledge one could expect from a physician, and Nicias implies that popular opinion would not expect much. It is indeed curious that he asks Laches specifically about a doctor's ability to decide whether all patients are necessarily worth treating or not, and they end up agreeing that this is beyond his normal purview. The physician's job, according to this formulation, is only to articulate what is or is not illness, although he essentially implies that an "ideal" physician (who would be able to discern what is truly "fearful" [ deina] and "to be dared" 
[tharralea]) would be able to prognosticate more accurately about a given disease, and decide whether treatment was even indicated. Nicias does not seem especially hopeful that physicians-or any craftsman, for that matter-would ever display this skill, but several times in the discussion, they assume that it is hypothetically possible. At 195d7, for example, Nicias claims that a physician cannot really distinguish whether a patient is better off dead, and what things would be fearful to which sort of patient, "except the one who knows the difference between what is and is not fearful, whom I call courageous"

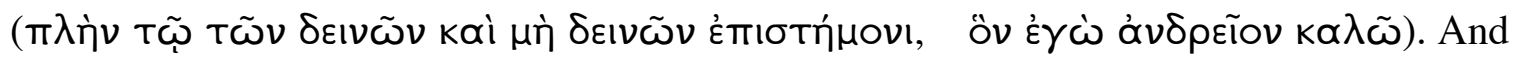
later, at 196d4, Socrates notes that few would be able to possess Nicias' criterion for courage (knowledge of the fearful and what should be dared): "neither the physician nor the seer will understand this, and won't be courageous, unless he can actually apply this

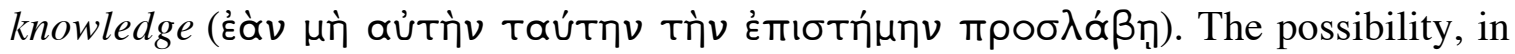
other words, that physicians might in fact possess a genuinely informed technê about the prognosis of diseases and the appropriateness of treatment (or non-treatment) is clearly entertained, even if these interlocutors might be hard pressed to think of any good examples. Nevertheless, we may remember that such a physician, however hypothetical in their minds, would, according to Nicias' definition, possess true andreia.

Socrates, for his part, fundamentally endorses Nicias' notion of andreia, but adds that the courageous man will have knowledge of past and present deina and tharralea as well as of future ones. Again, medicine serves as an illustrative example:

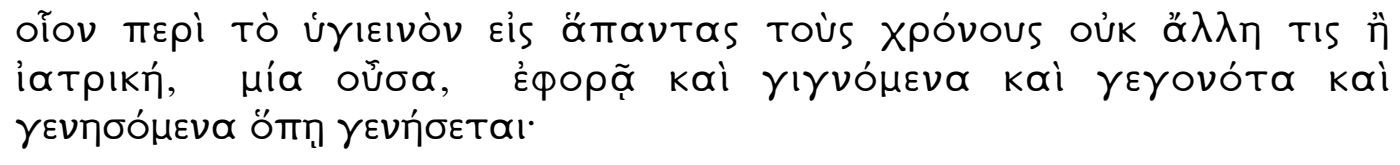

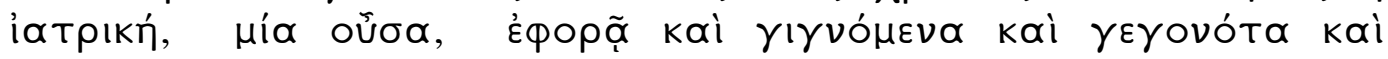

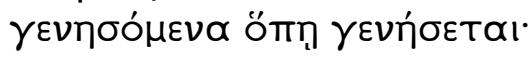


For example, when it comes to health, there is no art other than medicine directed at all periods of time, which, though a single art, surveys present, past and future, how things will happen.

He proceeds with a similar argument for farming and generalship, concluding that in all such cases andreia consists in the knowledge of past, present and future goods and evils idiosyncratic to each field. In part, this argument is intended to echo Nicias' earlier assertion at $196 \mathrm{a} 2$ that the seer's art, despite its ability to describe fearful or hopeful future events, is not necessarily courageous, since the seer need not comment on whether such events are beneficial to a person. At the same time, however, Socrates wants to retain the notion that andreia does imply at least some prognosticatory skill-one needs a full and genuine understanding of how events will turn out in order to act prudently and courageously. ${ }^{19}$ Without this, one's behavior is little more than some form of recklessness or madness. ${ }^{20}$

${ }^{19}$ If courage was felt to require knowledge of when a person can successfully fight and when he must withdraw, one wonders what exactly Thucydides thought of the physicians at 2.47.4, who lost their lives in droves trying to minister to the sick: "...Nor were the doctors, at first trying to practice their therapy in ignorance, strong enough [against it].

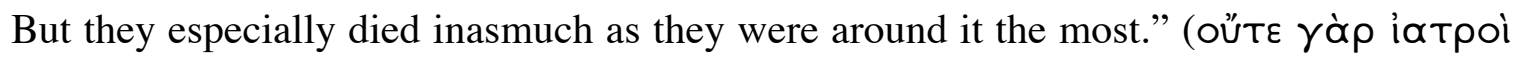

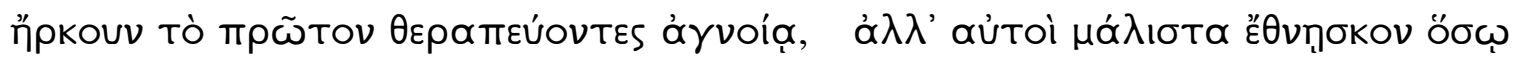

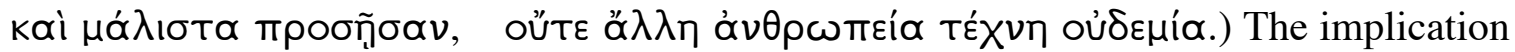
seems to be that it was essentially ignorance that killed these poor doctors, and that if they had understood the real power of the plague, they would (and should) have acted differently. This was no real courage, but lack of experience and insight, much as Socrates holds in Laches. See Horstmanshoff 1989, 1992 and 1993. 
It should be clear by this point that the Hippocratic author of De Arte was trying to make exactly this point about his own technê, even if he did not focus on andreia as such. Indeed, his entire argument defending the Hippocratic refusal to treat incurables privileges the same prognosticatory skills that Nicias regards as essential for the andreios man. The physician's ability to make a cogent decision about whether or not to take on a case, after all, presupposes an understanding both of what a patient should fear and not fear, and of what would be the most beneficial course of action for him. In the opening paragraph of the Hippocratic Prognostic, in fact, we find a clearly articulated programmatic rationale of the role of forecasting in medicine, which attests not only the practical but the moral advantages of prognosticatory skill:

${ }^{20}$ See Nicias' formulation at $197 \mathrm{~b}-\mathrm{c}$, which Socrates would almost certainly endorse, as far as it goes: "By no means, Laches, do I call courageous wild beasts or anything else that, for lack of understanding, does not fear what should be feared. Rather I would call them rash and mad...My view is that very few have a share of courage and foresight, but that a great many, men and women and children and wild animals, partake in boldness and audacity and rashness and lack of foresight. These cases, which you and the man in the street call courageous, I call rash, whereas the courageous ones are the sensible people I was talking about." [Tr. Sprague]. See also the similar discussion in Plato Prt.

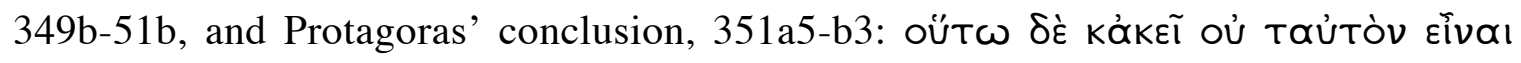

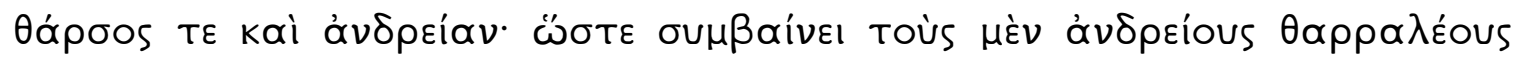

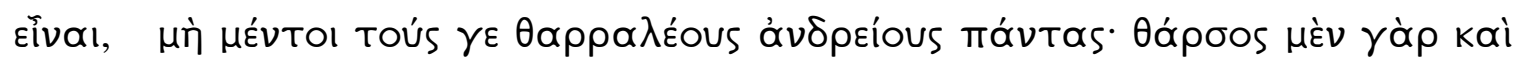

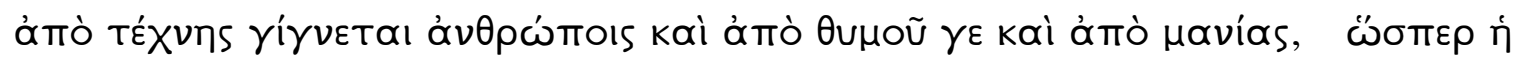

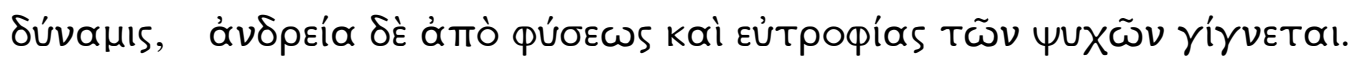




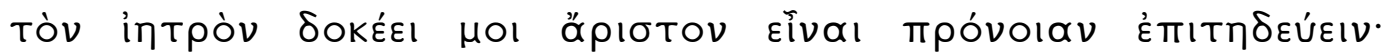

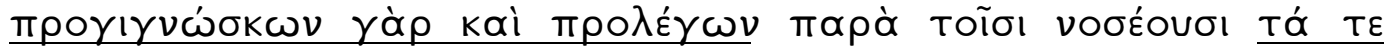

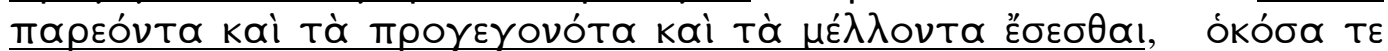

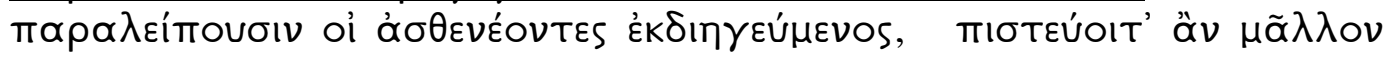

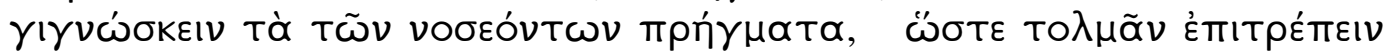

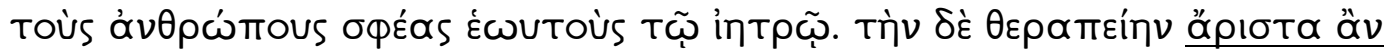

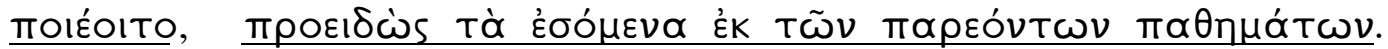

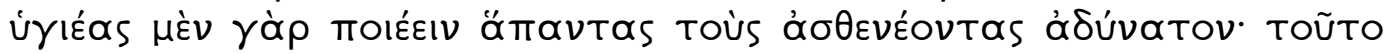

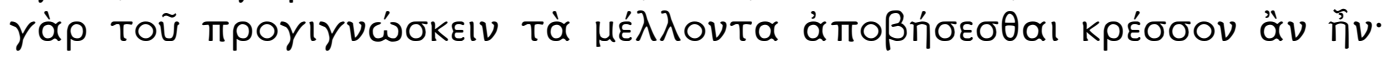

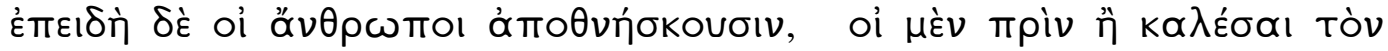

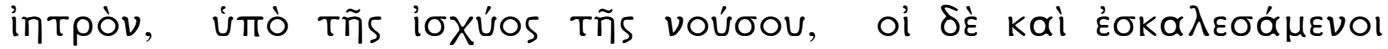

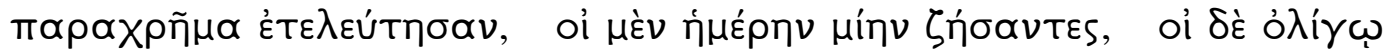

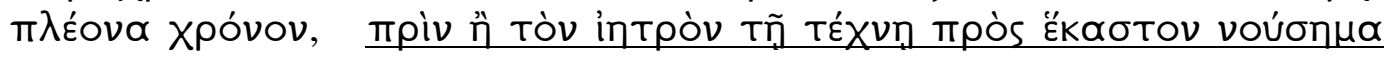

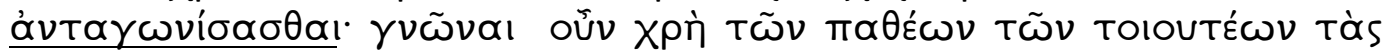

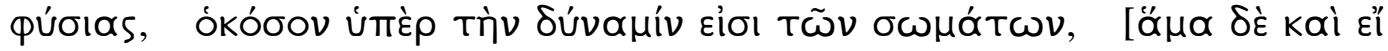

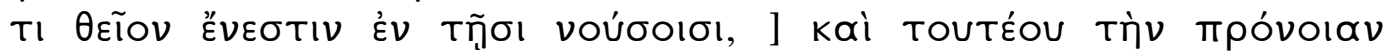

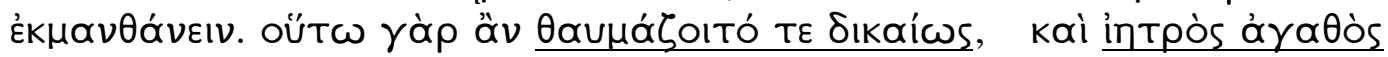

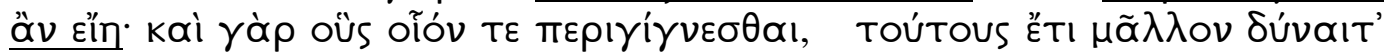

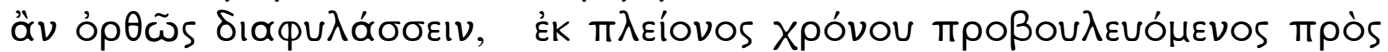

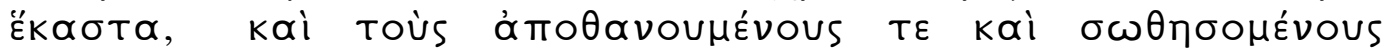
$\pi \rho \circ \gamma$ ry

I hold that it is an excellent thing for a physician to practice forecasting. For if he discover and declare unaided by the side of his patients the present, the past and the future, and fill in the gaps in the account given by the sick, he will be the more believed to understand the cases, so that men will confidently entrust themselves to him for treatment. Furthermore, he will carry out the treatment best if he know beforehand from the present symptoms what will take place later. Now to restore every patient to health is impossible. To do so indeed would have been better even than forecasting the future. But as a matter of fact men do die, some owing to the severity of the disease before they summon the physician, others expiring immediately after calling him in-living one day or a little longer-before the physician by his art can combat each disease. It is necessary, therefore, to learn the nature of such diseases, how much they exceed the strength of men's bodies, and to learn how to forecast them. For in this way you will justly win respect and be an able physician. For the longer time you plan to meet each emergency the greater your power to save those who have a chance of recovery, while you will be blameless if you learn and declare beforehand those who will die and those who will get better. (Tr. Jones)

The emphasis on the physician's knowledge of "past, present and future" in the first sentence is strikingly reminiscent of the description of medical prognosis in Laches, as is 
the importance given to an intellectual understanding of the entire course of a disease. ${ }^{21}$ Further, both passages hold that the best physicians will display the best skills in prognosis; proper technical knowledge, in short, is the sine qua non of an ethically appropriate medical practice. Once again, this passage shows just how "public" medicine

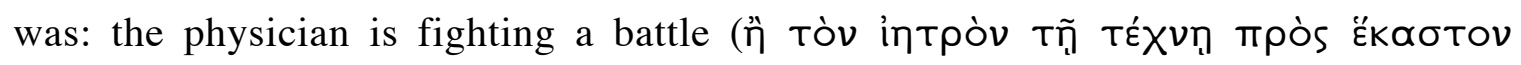

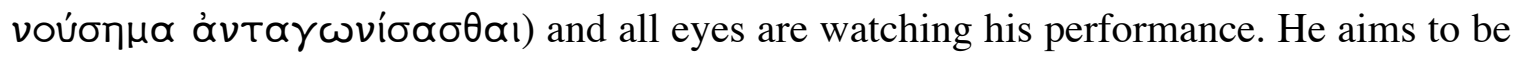
admired for his skills, but he wants this admiration to be won with integrity. As the author states, if a physician can prognosticate well, he will be "justly admired" (...åv

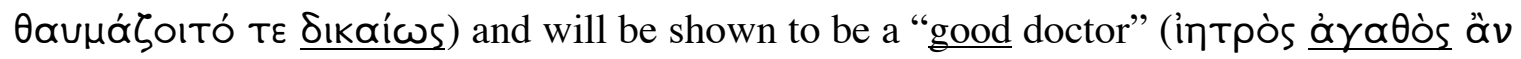
Eln). We may contrast this remark with the passage in De Arte we discussed earlier (see above 000) where the author complains about unscrupulous physicians who take on inappropriate cases in order to secure the admiration of charlatan physicians (and

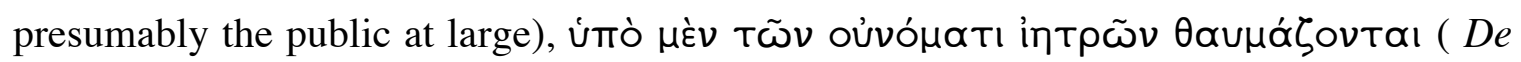
Arte 8). ${ }^{22}$ This author, as we have seen, chastises such physicians as part of his explicit defence of the principle of not treating incurable patients.

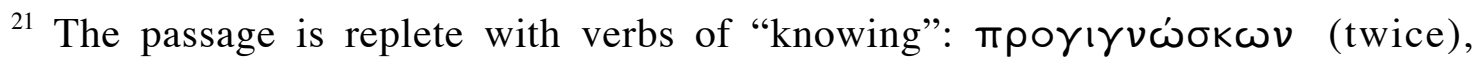

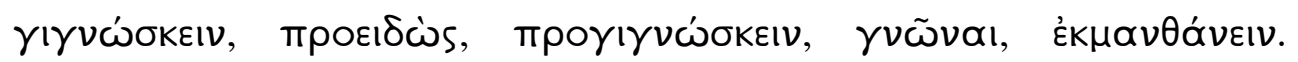

${ }^{22}$ Not much had apparently changed even by the early seventeenth century, when the narrator of Jonathan Swift's Gulliver's Travels (part 4, ch. 6; Landa 1960, 205) in describing English culture to the equine Houyhnhnms, reserves this barb for the contemporary physician: "One great Excellency in this Tribe is their Skill at Prognostics, wherein they seldom fail; their Predictions in real Diseases, when they rise to any Degree 
In Prognostic, the problem of incurables is likewise at issue, except in a more positive, and slightly more oblique, way. The author's point in the final sentence of the quoted passage is that proper prognosis will allow the physician to treat his patients more effectively and to "declare beforehand those who will die and those who will get better"

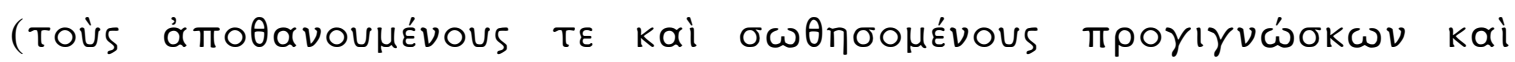

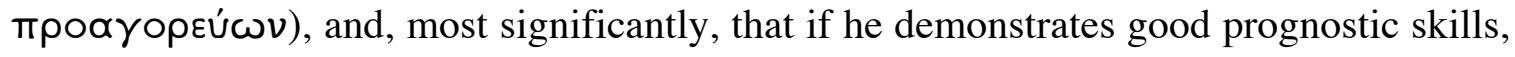
he will be held blameless (a̛vaítıos ơv Eîn) for his judgments about recovery and nonrecovery. Behind this statement lie clear traces of the contemporary debate about incurable patients, for we can assume that when the author speaks of a physician

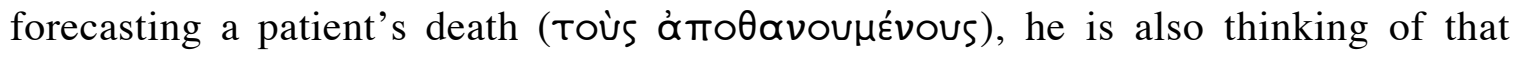
physician's refusal to take on such a case. Someone at some time was evidently always "blaming" physicians for their stance on whom to treat, but, the author claims, if one can show genuine skill in prognostics, the refusal to treat certain patients is not only rationally defensible but morally justified.

Like most of the Hippocratic treatises, De Arte and Prognostic cannot be dated with any precision, but there is general agreement, both in antiquity and now, ${ }^{23}$ that they were each composed some time in the late fifth century BC. By the time Plato wrote his

of Malignity, generally portending Death, which is always in their Power when Recovery is not: And therefore, upon any unexpected Signs of Amendment, after they have pronounced their Sentence, rather than be accused as false Prophets, they know how to approve their Sagacity to the World by a seasonable Dose.”

${ }^{23}$ On the dating of De Arte, see Gomperz $\left(1910,2^{\text {nd }}\right.$ ed.) [xx] with more recent bibliography in Cordes (1994) 101, n. 63. For Prognostic, see Alexanderson (1963) [xx]. 
Laches in the next century, then, the debates about the treatment of incurables must have been well delineated, especially as "Hippocratic medicine"-both as an abstract construct and a practical methodology-became more clearly articulated in contrast to other therapeutic approaches. It is unclear whether Plato himself first made the connection between andreia and medical prognosis, but if he did, it seems to me, he was only expressing ideas already latent within Hippocratic deontological discourse. From the passages we have discussed, it is apparent that, at least in the matter of incurable patients, these physicians felt continually called upon to defend a point of view that clashed with popular conceptions of proper medical conduct, just as in Laches, Plato's Socrates, in concert with Nicias, is clearly struggling towards a more rarefied conception of andreia than what most people would presumably have endorsed. As such, the debate between those physicians who unreflectively took on all cases regardless of their prospects for recovery, and those who refused incurable patients was fundamentally a debate between two conceptions of heroism, each with its own criteria for andreia. The one we might characterize as the traditional and popular version, which valued daring and endurance regardless of the chances of victory (and sometimes all the more in direct proportion to decreasing odds for survival!). The other examined a given situation in which such qualities as daring and endurance might be called for, assessed the risks, and considered what the benefits of "courageous" action were likely to be. The criterion in these cases was reason and knowledge, rather than reflexive emotion or a penchant for martyrdom, but the result looked quite different from what one commonly considered andreia. Indeed, although it may seem rather alien to us, the Hippocratic insistence on a rational 
University of Pennsylvania Page 27 of 30

foundation for their methods must have been a minority view that required its own kind of andreia to pursue. 


\section{Works Cited}

P. Cordes, Iatros: Das Bild des Arztes in der griechischen Literatur von Homer bis Aristoteles. (Stuttgart 1994),

Horstmanshoff, H.F.J. (1989), De pijlen van de pest. Pestilenties in de Griekse wereld, (diss. Leiden), Amsterdam.

- - - - . (1992), 'Epidemie und Anomie', Medizinhistorisches Journal 27, 43-65

- - - - - 1993. 'Les répercussions de la peste d'Athènes (430-426 av. J.- C.)' in: F.-O. Touati (ed.), Maladies, Médecine et Sociétés, approches historiques pour le présent, tome I, Actes du VIe Colloque d'histoire au présent, Parijs, 1993, 125-135.

— 'The ancient physician: craftsman or scientist?' in: Journal of the History of Medicine and Allied Sciences 45 (1990) pp. 176-197.

Jouanna, Jacques. 1999. Hippocrates (translated by M. D. DeBevoise). The Johns Hopkins University Press: Baltimore and London.

Parry, A. 1969. “The language of Thucydides' description of the plague”, Bulletin of the Institute of Classical Studies of the University of London 16, 106-118.

Schrijvers, P.H. 1990. 'Douleur, où est ta victoire? A propos de la letter 78 de Sénèque', Mnemosyne 43, 374-394.

Sontag, Susan. 1977. Illness as Metaphor. New York: Vintage Books.

Spira, A. (1987), 'Angst und Hoffnung in der Antike', in: 'F.R. Varwig (ed.) (1987), Ainigma. Festschrift für Helmut Rahn, Heidelberg, 129-183 
von Staden, H. 1987. 'Incurability and hopelessness: the Hippocratic Corpus' in: P. Potter, G. Malloney en J. Desautels (ed.), La maladie et les maladies dans la Collection Hippocratique, Actes du VIe Colloque International Hippocratique, Quebec, 76-112.

van der Eijk, Philip. 1999. "Helpen of niet schaden. Enkele uitgangspunten en methoden van therapeutisch handelen in de klassieke Griekse geneeskunde', Hermeneus 71.66-71.

Walsh, J. 1931. "Refutation of the charges of cowardice against Galen." Annals of Medical History 3, 195-208.

Wittern, Renate. 1979. "Die Unterlassung ärtztlicher Hilfeleistung in der griechischen Medizin der klassischen Zeit.” Münchener medizinische Wochenschrift 21.731-34. 
University of Pennsylvania Page 30 of 30

NOTES 